\title{
Test af studerendes begrebsforståelse
}

\author{
Simon Olling Rebsdorf er adjunkt, Center for Naturfagenes Didaktik, Steno Instituttet, Aarhus \\ Universitet. Her arbejder han med udvikling af naturfagenes undervisnings- og eksamensformer.
}

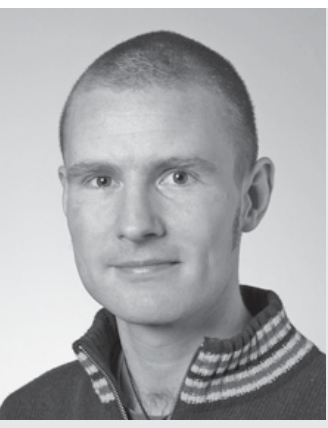

Simon Olling Rebsdorf er uddannet cand. scient. i videnskabshistorie (speciale) og fysik (hovedfag) og er ph.d. i videnskabshistorie fra Steno Instituttet, Aarhus Universitet. Han har desuden arbejdet som ideudvikler og opfinderrådgiver ved Center for Opfindelser og Kreativitet, Teknologisk Institut, og har i den forbindelse beskæftiget sig med kreativitetsbegrebet og begrebsændringer på forskellige niveauer.

Han har siden 2004 været ansat som adjunkt i universitetspædagogik ved Center for Naturfagenes Didaktik på Steno Instituttet, og interesserer bl.a. sig for grænsefladen mellem humaniora og naturvidenskab, som er et væsentligt element i praktisk samarbejde med universitetspædagogik i den naturvidenskabelige kultur. Stillingen omfatter universitetspædagogisk forskning, undervisning, rådgivning og udviklingsarbejde ved Det naturvidenskabelige Fakultet.

\section{Reviewet artikel}

Denne oversigtsartikel prosenterer aspekter af den såkaldte Force Concept Inventory test til måling af studerendes begrebsforståelse i introducerende fysikkurser. Artiklen beskriver testens rationale, giver et overblik over testens fremkomst og presenterer de konklusioner, uddannelsesforskere har draget af testens interessante resultater samt forskellige kritikpunkter af testen. Endelig inddrages en kvalitativ diskussion af testens anvendelse $i$ en dansk universitetspadagogisk sammenhong.

Siger tests mest om sig selv eller tester de faktisk det, de formodes at teste? Dette og lignende spørgsmål har taget rigelig spalteplads i tidens offentlige uddannelsesog evalueringsdebat. Jeg vil med denne artikel forsøge at tilføre diskussionen et informeret bidrag fra den naturvidenskabelige uddannelsesforskning. Det viser sig, at det inden for det fysiske fagområde tilsyneladende giver mening at teste for noget så kompliceret som begrebsforståelse. Samtidig er det dog vigtigt at gøre sig testenes begrænsninger klart.
Spændende empiriske resultater af omfattende tests af studerende ved nordøstamerikanske universiteter har vist, at 'interaktivt-engagerende' undervisningsstrategier sikrer bedre begrebsforståelse og måske endda bedre problemsløsningskompetencer end tilfældet er ved mere 'traditionelle', passiviserende undervisningsmetoder.

Hvor trivielt det end må synes for den garvede underviser, er der imidlertid tale om omfattende empiriske studier, som har fået betydning inden for samfundet af fysikundervisere og uddannelsesforskere, også i særdeleshed i Skandinavien. Som følge af testresultaternes solide empiriske slagkraft - men også af andre grunde - har testene i nogle år også trivedes på danske naturvidenskabelige fakulteter.

I den sammenhæng er det en diskussion værd, hvordan sådanne tests meningsfuldt kan og bør benyttes $\mathrm{i}$ det danske universitetssystem. Dette mener jeg passende kan ske i nærværende universitetspædagogiske tidsskrift, dels for at bringe naturfagsdidaktikken i spil som et slagkraftigt område i universitetspædagogikken, dels med henblik på inspiration til pædagogiske og didaktiske områder forankret $\mathrm{i}$ andre videnskabelige felter end det naturvidenskabelige.

\section{Beskrivelse af Force Concept Inventory}

De såkaldte Concept Inventory tests har udviklet sig til en mindre industri inden for amerikansk uddannelsesudvikling, kursusinnovation og studenterevaluering, ikke bare i fysik, men også i bl.a. kemi, biologi, astronomi og geovidenskab. I fysik begynder historien med Concept Inventory tests i klassisk mekanik. Men inden testens fremkomst skitseres, beskrives testens idé og rationale. 


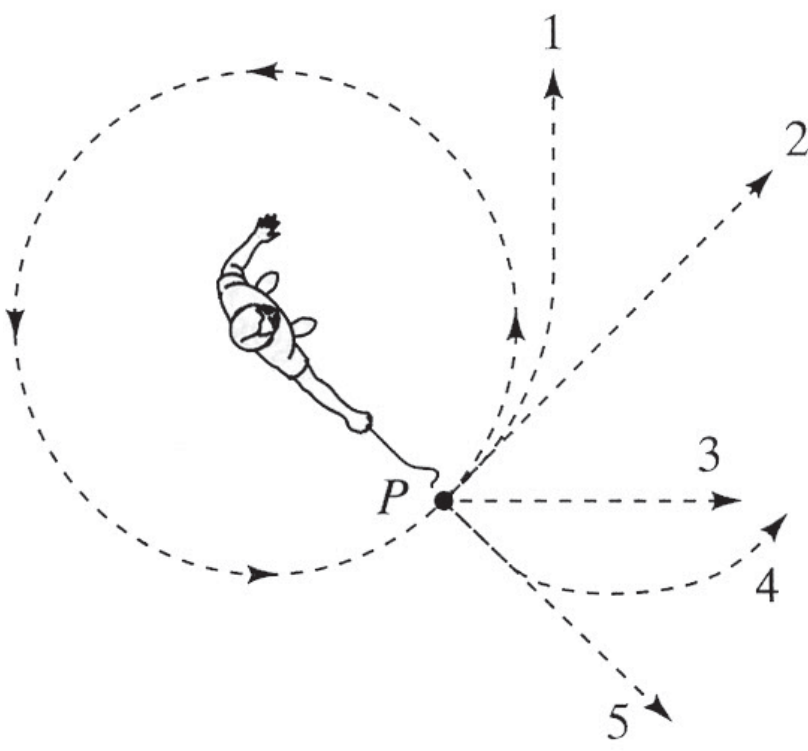

Figur 1

En stålkugle fastgjort til en snor svinges $i$ en cirkular bane $i$ det horisontale plan som illustreret ovenfor, hvor begivenhederne observeres direkte fra oven. I punktet P knokker snoren pludselig over, toet på kuglen. Hvilken af banerne 1-5 i figuren beskriver bedst kuglens bane efter at snoren knokker? (Sporgsmål nr. $7 i$ Force Concept Inventory testen, forfatterens oversattelse fra $\mathrm{Ma}$ zur $(1997,47)$ ).

Force Concept Inventory testen (FCI) gives til studerende, inden de påbegynder et introducerende kursusforløb i klassisk mekanik. Denne pre-test består af 30 kvalitative multiple choice spørgsmål, hvor hvert spørgsmål typisk har 4-5 svarmuligheder (et eksempel på et testspørgsmål er givet i figur 1). Efter kursets afslutning gives nøjagtig den samme test til den selv samme gruppe studerende (post-test), og underviseren har nu mulighed for at sammenligne pre-tests med post-tests. Under den antagelse, at FCI testen faktisk måler begrebsforståelse, kan underviseren således se, om den enkelte studerende samt hele holdet har opnået en forståelsesmæssig gevinst i undervisningsforløbet. Der kan sammenlignes med tidligere års tests, og der kan måske oven i købet sammenlignes med andre universiteter, der udbyder lignende kursusforløb.

Den udregnede gevinst for et studenterhold, dvs. det "gennemsnitlige, normaliserede gain« g, defineres ved forholdet mellem den faktiske gennemsnitlige tilvækst for et studenterhold og den størst mulige tilvækst for holdet (Hake, 1998, 65).

På individuelt niveau vil en studerende, der eksempelvis har svaret $20 \%$ af spørgsmålene rigtigt i pre-testen, have mulighed for at forbedre sig med de resterende $80 \%$ (= den størst mulige gevinst). Hvis post-testen $\mathrm{fx}$ viser en korrekt-svar procent på $50 \%$, vil g-værdien være

$$
\mathrm{g}=(50 \%-20 \%) / 80 \%=30 / 80=37,5 \% \text {. }
$$

Et springende punkt er naturligvis antagelsen om, at $\mathrm{g}$ er et gyldigt mål for undervisningens effektivitet for fremme af de studerendes begrebsforståelse. Man har nærmest pr. konvention sat et højt gain til over 70 procent, en middel gain-værdi til mellem 30 og 70 procent, mens et gennemsnitligt normaliseret gain på under 30 procent regnes for at være lavt (Hake, 1998, 65).

\section{Hverdagsforestillinger og testens rationale}

Rationalet bag FCI testen er at teste de studerende $\mathrm{i}$ seks forskellige begrebsdimensioner inden for fagområdet kraft og kinematik, som dækkes $i$ et introducerende mekanik-forløb på universitetsniveau. De seks dimensioner er kinematik (bevægelseslære), Newtons første, anden og tredje lov, superpositionsprincippet samt forskellige typer kræfter (fx kontakt-, friktions- og gravitationskræfter) (Hestenes et.al., 1992).

Til disse seks dimensioner har flere forfattere knyttet et klassifikationssystem af udbredte misforståelser - eller 'hverdagsforestillinger' - om disse begreber, herunder bl.a. 'aristoteliske ideer' om impetus, aktive kræfter (fx den udbredte misforståelse at bevægelse fordrer en aktiv kraft) og aktion/reaktion-par (fx at større masse betyder større kraft).

Adskillige konstruktivistisk orienterede naturfagsdidaktiske studier viser, at hverdagsforestillinger om fysiske begreber og begrebssammenhænge kan være ganske sejlivede. På trods af laboratorieforsøg, der viser det modsatte, kan en studerende alligevel fastholde sin hverdagsforestilling. Modstridende opfattelser kan altså befolke studenternes bevidste tankegang på samme tid. ${ }^{1}$ Bevidsthed om mulige hverdagsforestillinger spiller en stor rolle for den enkelte undervisers forståelse af sine studerende, samt for hendes planlægning af undervisningsforløb. Dette vil jeg ikke dvæle ved her. I stedet tjener det et formål at se kort på FCI testens udviklingsforløb, på forskellig kritik af testen, og dernæst lade blikket falde på danske forhold.

\section{FCI testens fremkonst}

Forløberen for FCI testen var den såkaldte Mechanics Diagnostics test (MD), som forste gang blev publiceret i 1985 (Halloun \& Hestenes, 1985). Testens formål var at give kendskab til studerendes viden om - og forståelse af - klassisk (newtonsk) mekanik vha. en række diagnosticerende spørgsmål. Testen blev administreret $i$ et åbent svarskema for college-studerende på introducerende niveau, og den udviklede sig til forskellige versioner af multiple choice skemaer, der testede mere end 1.000 studerende.

I 1992 lancerede David Hestenes m.fl. så den oprindelige version af FCI testen, og omkring halvdelen af spørgsmålene var gengangere fra MD-testen (Hestenes et al. 1992). ${ }^{2}$ Rationalet bag denne test var, at den skulle give en mere systematisk og fuldstændig profil af 
forskellige hverdagsforestillinger. Desuden fremhævede forfatterne, at FCI testen havde både et pædagogisk og et forskningsmæssigt sigte. FCI testen vandt indpas på stadig flere nordamerikanske universitetsinstitutioner, og reviderede versioner af testen blev publiceret på Internettet i 1995 (Halloun et al., 1995) og igen i Eric Mazurs bog Peer Instruction fra 1997 (Mazur, 1997). ${ }^{3}$

En interessant forskningsartikel af Richard Hake i American Journal of Physics initierede i 1998 debat blandt fysikundervisere og uddannelsesforskere (Hake, 1998). Artiklen baserede sig på omfattende pre/posttests (bl.a. FCI og MD tests) af over 6.500 første-semester studerende ved en række nordøstamerikanske universiteter med forskellige undervisningstraditioner. Hakes tese var, at det er muligt at måle de studerendes begrebsforståelse, både for og efter formel undervisning i klassisk mekanik, og derved at måle undervisningens effektivitet for de studerendes begrebsforståelse. Ifølge Hake var styrken ved testen, at de kvalitative spørgsmål kan undersøge begrebsforståelsen på en måde, der er meningsfuld for novicen, der ikke har fulgt universitetsundervisningen endnu, men som samtidig er tilstrækkelig krævende for den indviede.

\section{Amerikanske resultater}

Forskningsresultaterne som blev fremfort af Hestenes m.fl. i 1992 var bl.a., at studerendes pre-test resultater generelt ligger meget lavt, hvilket optimistisk kunne formuleres derhen, at der i de fleste tilfælde vil være et stort udviklingspotentiale. Desuden er der tilsyneladende ingen sammenhæng mellem post-test resultater og studerendes socio-økonomiske niveau. Der er ikke fortilfælde for store gain-værdier, når de testede studerende har modtaget traditionel undervisning, og der er ikke fundet korrelation mellem post-test resultater og underviserkompetencer - med enkelte undtagelser (Savinainen \& Scott, 2002a, 49). Endelig betragtes en FCI score på under 60 procent rigtige ud af de $30 \mathrm{mu}-$ lige som udtryk for, at testpersonen ikke har tilstrækkelig fat i newtonske begreber til at kunne løse mekaniske problemstillinger tilfredsstillende (FCI score er begribeligvis ikke det samme som gain-værdi). Desuden anses en FCI score på over 85 procent rigtige som udtryk for, at man behersker begreberne i klassisk mekanik.

Hake (1998) sondrede mellem »traditionelle« (T) og »interaktivt-engagerende« (IE) undervisningsmetoder. Med IE-undervisningsmetoder menes metoder, der er designet $\mathrm{i}$ det mindste for delvist at fremme begrebsforståelse gennem 'interaktiv indgriben' $i$ de studerende vha. 'heads-on' og 'hands-on' aktiviteter, som giver øjeblikkelig feedback via diskussion med sidemanden eller med underviseren. MedT-undervisningsmetoder menes til gengæld metoder, der ikke gør brug af IE-metoder, dvs. som hovedsagelig bygger på en-vejs kommunikerede forelæsninger med passive studerende, men også fx kogebogs-laboratorieøvelser (Hake, 1998, 65).
Hvis man accepterer antagelsen om målbarheden af begrebsforståelse, viser den mere interessevækkende del af undersøgelsen, at Hake på basis af sit solide empiriske materiale og omfattende statistiske analyse kunne konkludere, at aktiverende undervisningsformer giver en højere gevinst (højere gain) end traditionelle metoder. Dette udsagn kunne synes oplagt for mange undervisere, men det blev nu altså bestyrket med empirisk evidens.

Det spændende resultat af undersøgelsen var altså kort sagt, at 'aktiverende' undervisningsstrategier lader til at sikre bedre begrebsforståelse - og muligvis bedre problemsløsningskompetencer - end mere 'traditionelle' undervisningsmetoder.

\section{Kritik af FCI testen}

En række kritikpunkter er blevet fremført lige siden testen blev lanceret. Det er ikke målet med denne artikel at gå dybt ind i den diskussion, da en sådan må føres på et informeret og mere velunderbygget grundlag, og jeg må her nøjes med at henvise til den internationale litteratur. ${ }^{4}$

\section{Ingen garantier}

Som allerede antydet har de vedtagne grænseværdier for FCI scoren på hhv. 60 og 85 procent et anstrøg af tilfældighed over sig, eller i hvert fald går kritikken på, at der ikke er videnskabelig evidens for fastsættelsen af disse særlige værdier. Mere interessant har den britiske fysiker Sanjoy Mahajan på trods af yderst gode FCI testresultater (med de laveste på 83,3 \% - og således motiveret af en sund skepsis) afsløret, at en gruppe studerende alligevel havde alvorlige problemer med newtonsk tænkning under arbejdet med mekanikøvelser i nogle ugentlige supervisionslektioner (Mahajan, 1999). På trods af de gode testresultater havde flere af de studerende hverdagsforestillinger om kræfter. Om end der er tale om begrænsede undersøgelser udført af Mahajan, søsættes hermed en vis skepsis overfor testens gyldighedsområde og beskrivelseskraft. Men som fremhævet af Savinainen \& Scott kan en lav FCI score nok give information om, at en studerende ikke har forstået kraftbegrebet, "men en høj FCI score ser ikke ud til at garantere, at den studerende kan anvende newtonsk tænkning på ukendte problemstillinger.« (Savinainen \& Scott 2002a, 50) Budskabet er altså, at testen kan bruges diagnostisk til at identificere forståelsesproblemer - i tilfælde med en lav FCI score - men ikke til at sikre, om studerende, der klarer sig godt i testen, har forstået alle aspekter af det klassiske kraftbegreb. Testen giver med andre ord ingen forståelsesgarantier, men kan til gengæld benyttes til at udpege nogle tendenser i studerendes forståelse.

Et andet kritikpunkt, som gælder i mange andre testsammenhænge, er, at testen kun måler enkelte elementer af studerendes viden, som ikke nødvendigvis 
omfatter et samlet kraftbegreb. Fortalere for testen responderer imidlertid, at FCI scoren snarere er et mål for forskellen på de studerendes begrebsforståelse og de etablerede newtonske kraftbegreber (Hestenes \& Halloun, 1995).

\section{Testen kan og bor ikke stå alene}

Endelig er nogen kritik gået på Hakes oversimplificerede dikotomi for undervisningsmetoder: IE eller ikke-IE. Verden er mere nuanceret end som så, og det er omtrent lige vanskeligt at forestille sig begge yderpunkter: konstant interaktion mellem studenter og forelæser i den ene ende af aksen, og en forelæser uden nogen som helst kontakt med studenterpopulationen i den modsatte ende. Det kan naturligvis ikke være meningen, at undervisere tænker i så simplificerede læringstermer, og i øvrigt bør en FCI test ikke stå alene $\mathrm{i}$ en evalueringssammenhæng.

\section{Testens fremtidige anvendelse ved danske universiteter}

I Danmark har testen også vundet indpas. På introduktionskurset i Indledende Mekanik ved Institut for Fysik og Astronomi på Aarhus Universitet er der gennemført FCI tests af førsteårsstuderende i fysik og i nanoteknologi begyndende i 2000. Også ved Niels Bohr Instituttet, Københavns Universitet, er FCI testen anvendt på studerende, og Center for Naturfagenes Didaktik, $\mathrm{KU}$, har benyttet testen i introduktionskurset Fysik 1 i 2003 og 2004 (i efteråret 2005 benyttedes både FCI testen og Mechanics Baseline testen ${ }^{5}$ ). Endelig er civilingeniørstuderende $\mathrm{i}$ de seneste fire år blevet udsat for FCI testen på Danmarks Tekniske Universitet, mens studerende i teknisk fysik sammesteds har prøvet testen to gange indtil videre.

Center for Naturfagenes Didaktik i Århus forsøger nu i samarbejde med de to øvrige institutioner at sikre det statistiske grundlag for en sammenligning af data, med henblik på udvikling og kvalitetssikring af fysikundervisningen på det tertiære niveau (disse data foreligger imidlertid endnu ikke til en samlet offentliggørelse).

De danske FCI tests er i forskellig grad blevet benyttet til både systematisk undervisningsudvikling med henblik på fremtidssikring af undervisningen ${ }^{6}$ og til forøget bevidsthed blandt underviserne om de studerendes begrebsforståelse med henblik på en fokusering af indsatsområder i den løbende udvikling af fysikkurserne. FCI testen benyttes også med fordel til sammenligning med tidligere år, for derved at opnå viden om årgangenes forskelle i styrker og svagheder - igen med henblik på undervisningsplanlægningen.

Det er imidlertid ikke min opfattelse, at testene er blevet benyttet som målestok eller katalysator for ændringer af evt. 'traditionelle' undervisningsformer, som Hake 1998 lægger op til. Dette skyldes nok hovedsagelig manglen på 'kontrolgrupper', der modtager andre former for undervisning. Men selvom vi fik adgang til sådanne studentergrupper, er det vanskeligt at forestille sig en målbar effekt á la Hake. En årsag hertil ville formodentlig være den oplagte, at der er ganske stor forskel på undervisningstraditionen i USA og i Danmark. Hvor forelæsninger i USA udgør hovedparten af undervisningsaktiviteten på de store introduktionsforløb, spiller de i Danmark en mindre afgørende rolle, da vi har tungt vægtede teoretiske holdøvelser, som måske endda er det sted, hvor den dybeste læring sker! I USA vil ændringer i undervisningsformer, fx tiltag hen i mod mere aktiverende forelæsninger - som anbefalet af fx Donald Bligh (2000) eller Eric Mazur (1997) - således have større indvirkning på den enkelte studerende qua en mere ensidig undervisningsstruktur, mens det i en dansk sammenhæng formentlig vil være noget vanskeligere at udpege årsager til et evt. stort gain. Ikke desto mindre vil det være meningsfuldt for den fagligt kursusansvarlige at benytte testene som diagnosticerende instanser til udpegelse af bestemte underområder inden for faget, der kræver øget opmærksomhed eller bestemte studerende, der påkalder sig en ekstra undervisningsindsats.

\section{Sammenfatning}

FCI testen har haft stor indvirkning på amerikanske universiteter. Den er nem at administrere, hvilket selvfølgelig er bekvemt for den enkelte underviser. Men som Savinainen \& Scott præciserer - baseret på egne erfaringer - så kan testen indvirke væsentligt på både undervisere og dermed på undervisningen på et mere fundamentalt niveau (Savinainen \& Scott, 2002a og 2002b). Desuden fremhæves det, at underviseren i tilgift făr et meningsfuldt middel, der kan hjælpe til opsøgning af mere konkret og detaljeret information om den individuelle studerendes forståelsesniveau.

Underviserne får tillige, qua de seks veldefinerede begrebsdimensioner, et hjælpemiddel til fokusering af kursets læringsmål, eksamensformer og undervisningsmetoder - og de făr muligvis endda nogle vurderingskriterier, der kan implementeres i undervisningsevalueringer af de studerendes kursusudbytte. Dette er helt i tråd med John Biggs' alignment-terminologi for kvalitet i undervisning (også) på universitetsniveau (Biggs, 2003). Alignment-begrebet dækker over en ganske simpel, konstruktivistisk forankret, institutionel teori om motivations- og incitamentsstrukturer, der tager udgangspunkt $\mathrm{i}$ den studerendes synsvinkel. Hovedtesen går på det meningsfulde $i$ at sikre, at alle komponenter $\mathrm{i}$ undervisningssystemet arbejder hen $\mathrm{i}$ mod samme mål, og det er her især afgørende, at curriculum, undervisningsformer og vurderingsprocedurer svarer til hinanden.

(Sluttelig kan det afsløres, at svaret i figur 1 er: bane 2). 


\section{Litteratur}

- Biggs, John (2003), Teaching for Quality Learning at University: What the student does, Open University Press, Buckingham and Philadelphia.

- Bligh, Donald (2000), What's the Use of Lectures?, Jossey-Bass, San Fransisco.

- Ehrlich, Robert (2002), »How do we know if we are doing a good job in physics teaching? «, American Journal of Physics, 70 (1), 24-28

- Fagen, Adam P., Crouch, Catherine H., Mazur, Eric (2002),»Peer Instruction: Results from a Range of Classrooms", The Physics Teacher, 40, 206-209.

- Hake, Richard (1998), „Interactive-engagement versus traditional methods: A six-thousand-student survey of mechanics test data for introductory physics courses", American Journal of Physics, 66 (1), januar.

- Hake, Richard (2002), "Comment in "How do we know if we are doing a good job in physics teaching?, "by Robert Ehrlich [Ehrlich 2002] ", American Journal of Physics, 70 (10), 1058-1059

- Halloun, Ibrahim og Hestenes, David (1985), "The initial knowledge state of college physics students", American Journal of Physics, 53, 1043-1056.

- Halloun, Ibrahim, Hake, Richard, Mosca, E. og Hestenes, David (1995),«Force Concept Inventory (revised 1995)« I Mazur 1997.

- Hestenes, David og Wells, Malcolm (1992), „A Mechanics Baseline Test«, The Physics Teacher, 30(3), 159-166.

- Hestenes, David, Wells, Malcolm og Swackhamer, Gregg (1992), "Force Concept Inventory«, The Physics Teacher, 30, 141-158.

- Hestenes, David og Halloun, Ibrahim (1995), "Interpreting the Force Concept Inventory", The Physics Teacher, 33, 502-506.

- Mahajan, Sanjoy (1999), "Observations on Teaching First-year Physics - a report to the Cavendish teaching Committee", Cambridge University.

- Mazur, Eric (1997), Peer Instruction: A user's manual, Prentice Hall, New Jersey.

- Redish, Edward F., Saul, Jeffrey M., Steinberg og Richard N. (1997), "On the effectiveness of active-engagement microcomputer-based laboratories", American Journal of Physics, 65, 45-54.

- Redish, Edward F. og Steinberg, Richard N. (1999), "Teaching Physics: Figuring out what works", Physics Today, januar, 2430.

- Rosenberg, Jessica L., Lorenzo, Mercedes, og Mazur, Eric (2005), "Peer Instruction: Making Science Engaging«, indsendt til udgivelse i Handbook of College Science Teaching (kan downloades på http://mazur-www.harvard.edu (tilgået d. 2. oktober 2005).

- Rump, Camilla \& Horst, Sebastian (2005), Fysik 1 Design- og folgeprojekt, Blok 1, 2004. Center for Naturfagenes Didaktik (KU), maj, tilgået d. 1. oktober 2005 via www.cnd.ku.dk.

- Savinainen, Antti \& Scott, Philip (2002a), »The Force Concept Inventory: a tool for monitoring student learning «, Physics Education, 37(1), 45-52.

- Savinainen, Antti \& Scott, Philip (2002b), „Using the Force Concept Inventory to monitor student learning and to plan teaching «, Physics Education, 37 (1), 53-58.

- Sjøberg, Svein (1992), »Når virkeligheden konstrueres - læringspsykologi« I Henry Nielsen og Albert Chr. Paulsen (1992), Undervisning i fysik - den konstruktivistiske idé, Gyldendal, København.

- Sjøberg, Svein (2005), Naturfag som almendannelse: En kritisk fagdidaktik, Klim, Århus.

\section{Noter}

1 Se fx Redish \& Steinberg 1999, Sjøberg 1992, særlig s. 41-46 (og revideret i Sjøberg 2005, 232-243).

2 En anden mere kvantitativt orienteret problemløsningstest blev tillige lanceret samme år, nemlig den såkaldte Mechanics Baseline Test (MBT), en test der i år benyttes i fysikundervisningen på Københavns Universitet af Center for Naturfagenes Didaktik (Hestenes \& Wells, 1992).

3 FCI testen bestod i begyndelsen af 29 kvaltiative spørgsmål. I dag benyttes 30 spørgsmål, i fx (Mazur, 1997). FCI testen har i øvrigt været inspirationskilde til andre former for tests inden for fysikfaget og det har udviklet sig til en hel industri inden for studenterevaluering og undervisningsinnovation, fx Concept Inventory (CI) tests af studerendes begrebsforståelse inden for termodynamik (Thermal Science CI), elektromagnetisme (EMCI), dynamik (Dynamics CI: www.esm.psu/dsi), biologi (http://bioliteracy.net/), geovidenskab (Geoscience CI: http:// newton.bhsu.edu/eps/gci.html), astronomi (Moon CI: www. phys.ksu.edu/perg/www/pdf/moon.pdf), og også for kemi har man udviklet et spørgekatalog (alle Internetsider tilgået 2. oktober 2005).

4 Se fx en glimrende oversigtsartikel af Savinainen \& Scott (2002a), hvor kritikpunkter systematisk er fremført, og dele heraf er parafraseret i nærværende artikel. Diskussion findes tillige i Ehrlich 2002, Hake 2002, Savinainen \& Scott 2002b og Fagen et al. 2002. Om aktiverende undervisningsformer, se Redish et al. 1997, Rosenberg et al 2005. Eric Mazur står bag hjemmesiden for the Mazur Group på Harvard - en meget righoldig hjemmeside, hvor interesserede kan finde mere information og litteratur: http://mazur-www.harvard.edu (Tilgået 2. oktober 2005).

5 Omtalt i note 2. Se iøvrigt Center for Naturfagenes Didaktiks (KU) detaljerede rapport om kurset "Fysik 1: Design og følgeprojekt« (Rump \& Horst, 2005).

6 Se note 5. 